China Perspectives

$2015 / 2$ | 2015

Re-imagining the Chinese Worker

\title{
Editorial
}

\section{Wanning Sun}

\section{(2) OpenEdition}

\author{
Journals
}

Electronic version

URL: http://journals.openedition.org/chinaperspectives/6681

DOI: 10.4000/chinaperspectives.6681

ISSN: 1996-4617

\section{Publisher}

Centre d'étude français sur la Chine contemporaine

\section{Printed version}

Date of publication: 1 June 2015

Number of pages: $3-5$

ISSN: 2070-3449

\section{Electronic reference}

Wanning Sun, « Editorial », China Perspectives [Online], 2015/2 | 2015, Online since 01 January 2017

connection on 24 September 2020. URL : http://journals.openedition.org/chinaperspectives/6681 ;

DOI : https://doi.org/10.4000/chinaperspectives.6681 


\section{Editorial}

WANNING SUN

W hen the Chinese Communist Party (CCP) founded the People's Republic of China in 1949, it faced the enormous task of building not only a new national economy, but also a new class politics. Mao realised that a cultural transformation, rather than simply a political commitment, was necessary for his "continuous revolution." (1) For this purpose, how to mobilise workers and peasants, previously exploited and oppressed by landlords and capitalists, to identify with and actively participate in the socialist modernisation process became the biggest challenge. To this end, cultural production under the ideological tutelage of the CCP was geared toward actively promoting the idea of class identity transformation. In contrast to the revolutionary period, contemporary economic reforms and the embrace of the neoliberal economic order have led workers and peasants to lose their status as the "most advanced forces of production." The main beneficiaries and agents of economic growth in the decades of economic reforms since the early 1980s are "cadres, managers, and entrepreneurs," or what have come to be described as China's "new middle class," consisting of political and economic elites who are China's new "ruling classes." (2) In contrast, the political and economic interests of the "old Maoist working class," (3) consisting of workers and peasants, have been severely undermined. Formerly the political "mainstream" and "backbone" of socialist China, ${ }^{(4)}$ China's workers and peasants are now "losing [their] subjectivity and legitimacy" and "can no longer be called upon by national ideology." (5)

Although scholarship in the disciplines of sociology, political science, and economics points to the dramatic transformation of the political and economic fate of China's working classes from the Mao to the post-Mao period, a systematic attempt to trace the metamorphosis of the cultural politics of this transformation is still missing. Similarly, existing works have by default pointed to the dominance of class struggle in Mao's propaganda, as well as the subsequent disappearance of this narrative strategy and discursive position in the post-Mao period. But we still do not know what this disappearance means for the construction of working class identities in the reform era.

This is not to say that there is no cultural analysis of class politics in the historical periods preceding the economic reforms. As early as the 1920s, long before the Chinese Communist Party came to power and during its earliest formation, political elites were actively searching for ways to mobilise peasants and workers. Studying the process by which Anyuan mining workers became proletarian class subjects, Elizabeth Perry explores how the CCP actively pursued cultural forms and strategies that were inspired by the Stalinist modus operandi. For instance, "speaking bitterness" (su ku), which was to become a celebrated proletarian speech act, developed at the time when workers were required to give regular public speeches condemning the evils of private property and the class system, and extolling the virtue of overthrowing exploiters and oppressors. ${ }^{(6)}$ Similarly, artists and intellectuals, through their cultural roles in activities such as dance, music, painting, and public celebration and commemoration, were instrumental in constructing the propaganda of the newly founded People's Republic of China. (7)
It is true that most accounts of cultural production in the pre-reform era discuss the dominant themes of class consciousness and class struggle, and assume the privileged status of the working classes. However, with few exceptions, ${ }^{\left({ }^{8}\right)}$ representations of working class identities have seldom been the focus of analysis. Even fewer works consider how the imaginings of workers and peasants at different moments in history reference one another. As a consequence, a range of questions remain unclear. What media forms and cultural practices were associated with, and formed distinct aspects of, socialist working-class cultures? What genres and discursive strategies were instrumental in shaping a collective socialist working class identity and class consciousness? How are a range of issues, such as the meaning of labour, fairness, equality, exploitation, and labour relations, negotiated in media and cultural products, and how do they change over time? What are the major ways in which representations of the working classes in the socialist era get reworked and reproduced in the reform era? How does the exalted status of the proletarian working classes during the socialist period continue to provide moral, cultural, and discursive resources for today's grassroots workers' activism, Left-leaning intellectual movements, the Partystate's ideology, and market-driven popular culture?

Furthermore, the question of how these contradictory impulses interact in the symbolic battlefield, and with what political, social, and economic motives, causes, consequences, and ramifications, looms large.

\section{Themes and Arguments}

In her study of the revolutionary tradition, Perry argues that understanding the Chinese revolution requires knowing the role of culture, which should be "treated as a realm of fluid and often contradictory semiotic practices" requiring, from analysts, an "intimate familiarity with prevailing norms and habits." (9) Papers in this special feature were first presented at an interna-

1. Paul Clark, The Chinese Cultural Revolution: A History, Cambridge, UK, Cambridge University Press, 2008.

2. David S. G. Goodman, "Why China Has No New Middle Class: Cadres, Managers and Entrepreneurs," in David S. G. Goodman (ed.), The New Rich in China: Future Rulers, Present Lives, New York, Routledge, 2008, p. 24

3. Beatriz Carrillo and David S. G. Goodman, "Introduction:The Sociopolitical Challenge of Economic Change - Peasants and Workers in Transformation," in Beatriz Carrillo and David S. G. Goodman (eds), China's Workers and Peasants: Changing Class Identities, Cheltenham, UK, Edward Elgar, 2012, p. 3.

4. Yuezhi Zhao, "Chinese Modernity, Media, and Democracy: An Interview with Lü Xinyu," Global Media and Communication, Vol. 6, No. 1, 2010, p. 5.

5. Lü Xinyu, quoted in ibid., p. 6.

6. Elizabeth Perry, Anyuan: Mining China's Revolutionary Tradition, Berkeley, University of California Press, 2012, p. 127.

7. Chang-Tai Hung, Mao's New World: Political Culture in the Early People's Republic, Ithaca, Cornell University Press, 2011.

8. See, for example, Cai Xiang, Geming/xushu: Zhongguo shehui zhuyi wenxue wenhua xiangxiang (1949-1966) (Revolution/narrative: cultural and literary imaginary in socialist China [19491966]), Beijing, Beijing University Press, 2010; and Richard King, Milestones on a Golden Road: Writing for Chinese Socialism, Vancouver, UBC Press, 2013.

9. Elizabeth Perry, Anyuan: Mining China's Revolutionary Tradition, op. cit., p. 5. 
tional workshop on the cultural politics of class in socialist China at University of Technology, Sydney in December 2013. They embody what Perry calls a "cultural turn" in the study of China's working classes. More specifically, they are motivated to explore how class relations are managed and negotiated in cultural terms. The four papers appear in chronological order: Ying Qian examines a play set in a factory shopfloor in the revolutionary decade (1948), Qian Gong looks at films with industrial themes produced during the Cultural Revolution (1966-1978), Rosemary Roberts analyses TV adaptations of a Maoist classic in the third decade of the economic reforms (2006), and Wanning Sun considers the remembrance of workers' experience of socialism in television drama series produced within the last few years (2007-present). Taken collectively, the authors aim to make a number of interventions - methodological, empirical, and analytical.

First, either explicitly or implicitly, authors in this collection maintain that analysis of class politics must foreground cultural-political forms. In other words, questions regarding the politics of medium, genre, trope, and iconicity are central in tracing and capturing the working class identity formations as discourse, sentiment, and "structure of feeling." (10) Second, the authors in the collection argue that analysis of narratives, speech acts, and discursive practices of any given historical era - be it the revolutionary period, the early PRC, the Cultural Revolution, or the reform and post-reform periods cannot take place in isolation, as a temporally discrete and disconnected fragment. For this reason, the main analytic goal of the four papers included in this feature lies in tracking (dis)continuities from one era to another, as well as connections across eras. If the cultural formations of the pre-reform periods are found to be already inter-textual, inter-discursive, and inter-era, these characteristics have become so prominent in contemporary cultural productions that they in fact have defined and provided both the content and the raison d'être for their very existence. A key task for our project lies in tracking the major ways in which current ideologies, techniques, and aesthetics have evolved, percolated, and mutated in history.

Third, in their own ways, all four papers demonstrate that the formation of any given class identity takes place in relation to a class Other. For this reason, the inter-subjective dimension holds the key to unravelling the changing constructions of working class identities at all times. While the common goal in this special collection is to track the changing identities of China's workers and peasants from the socialist period to the present, such tracking cannot bypass the central role of the intellectual classes. Workers and peasants may be represented as heroes, protagonists, and positive role models in literature, films, plays, and journalism, or they may be represented as having fallen from these elevated statuses. But these representations are, in most cases, produced by "cultural workers," including writers, artists, and journalists who seek to represent them, the scholars and academics who research them, and audiences and the reading public who are curious to learn about their experiences.

Finally, for the authors of this collection it is important to demonstrate that cultural activities of constructing working class identities in all historical periods - revolutionary, socialist, and reform eras - take place against the backdrop of the changing conceptions of the Chinese Party-state. In the pre-reform eras, the Party-state was "forged in the anti-imperialist and anticapitalist social revolution, with a historically grounded popular base of legitimacy." (11) The past decades of economic reform show that the Chinese state is capable of reinventing itself. Despite the tension between the "party line" and the "bottom line," and the ensuing dichotomy between the official culture and popular culture, no artistic and media production operates out- side the regulatory framework - in either the ideological or institutional sense - of the one-party regime. Jiang Zemin's theory of the "three represents" may seek to change the CCP into a more democratic or inclusive party, but the CCP's propaganda and "thought work" continue to play a central role in maintaining its legitimacy and governance. ${ }^{(12)}$ Together, they trace the ambiguous and shifting relationships between the workers and peasants and intellectuals. They are also concerned with the metamorphosis of this relationship vis-à-vis the changing formations of the Party-state.

\section{Aims and approaches}

Papers in this collection take a diverse range of approaches. Papers by Ying Qian and Qian Gong look at media and cultural products/practices from Mao's time through a contemporary lens. In doing so, they pursue the agenda of excavating cultural scripts and media forms from historical ruins, restoring their place in history, and thereby testifying to the arbitrariness of official memory. Papers by Rosemary Roberts and Wanning Sun examine present renditions of past class experiences in ways that reveal the contemporary impulses for either reinstating a particular erased memory or for exploiting a versatile political-cultural icon. Despite the differences in approach, they share a dual objective. First, they seek to (re)interpret and (re)assess past working class experiences with the benefit of hindsight; second, they are concerned with finding ways of using these reinterpretations and reassessments of the past to illuminate the present. If it is true that, as Ching Kwan Lee observes, in the process of remembering the past, the present becomes "denaturalized" and "stripped of its given-ness," (13) the reverse is also true: the process of recalling the past can also denaturalise and strip the past of its given-ness.

In their own ways, these papers draw our attention to two mutually reinforcing political processes. We know that the elevation of the working classes in socio-political terms in revolutionary discourse goes hand in hand with the fanshen (worker emancipation) discourse and the cultural process of constructing class struggle discourse and mobilising class consciousness. Similarly, real or desired sea changes in subsequent eras in the destiny of the working classes have involved changing the ways in which the working classes are imagined, talked about, and represented in the cultural domain. This in some cases involves the excavation of unsanctioned and repressed memory that previously only existed in the form of dissent, opposition, and resistance. ${ }^{(14)}$ At other times, it involves changing the frameworks and lenses through which events are recalled and constructed. In this process of imagining and re-imagining, media and popular cultural productions are instrumental, actively turning someone's "newly experienced needs" (15) into a "common sense" view of the world.

10. Raymond Williams, Marxism and Literature, Oxford, Oxford University Press, 1977.

11. Yuezhi Zhao, Communications in China: Political Economy, Power and Conflict, Lanham, MD, Rowman and Littlefield, 2008, p. 177.

12. Anne-Marie Brady, Marketing Dictatorship: Propaganda and Thought Work in Contemporary China, Lanham, MD, Rowman and Littlefield, 2010, p. 5.

13. Ching Kwan Lee, "What Was Socialism to Chinese Workers? Collective Memories and Labor Politics in an Age of Reform," in Ching Kwan Lee and Guobin Yang (eds), Re-envisioning the Chinese Revolution: The Politics and Poetics of Collective Memories in Reform China, Washington, DC, Woodrow Wilson Center Press, 2007, p. 156.

14. Rubie Watson, "Memory, History and Opposition under State Socialism: An Introduction," in Rubie Watson (ed.), Memory, History and Opposition under State Socialism, Santa Fe, School of American Research Press, 1994, pp. 1-20.

15. Lisa Rofel, Desiring China: Experiments in Neoliberalism, Sexuality, and Public Culture, Durham, NC, Duke University Press, 2007, p. 14 
Furthermore, the process of re-imagining is imbricated with the action of remembering. In their collection on the intersections of politics, memory, and culture, Lee and Yang consider memory as simultaneously a political force and a cultural phenomenon. ${ }^{(16)}$ To approach memory as a political force, one must ask about the context, the meaning, and the effect of remembering the past. To approach memory as a cultural phenomenon, one must look into the technology and forms of narrative strategies, signifying processes, and remembering as a form of cultural practice. This includes genres, media, and sites through which memory is articulated and constructed. Papers in this collection are also concerned with the questions of if and how memories are used as a "critique of the present, or as an inspiration for an alternative future." (17)

But this collection wants to go further than proving that the past can be used to critique and illuminate the present, and the present can help us un- derstand the past better. These contributors have a more specific concern with exploring how the politics of memory and remembering is played out at a time when both the Chinese state and society have become the "site of struggle between competing bureaucratic interests, divergent social forces, and different visions of Chinese modernity." (18) In other words, in their own ways, these papers demonstrate that memory and remembering are useful to the leaders of today's workers' movement in their attempt to reinstate the "rightful" place of the worker and the working classes, to the Party-state in its current attempt to recoup moral and cultural resources for reconstituting core socialist values, and to Left-leaning intellectuals in their efforts to reclaim political legitimacy for the working classes, and finally, to those interested in finding new ways of governing the population in the neoliberal order by exploiting the moral resources of the socialist past.
16. Ching Kwan Lee and Guobin Yang, "Introduction: Memory, Power, and Culture," in Ching Kwan Lee and Guobin Yang (eds), Re-envisioning the Chinese Revolution:The Politics and Poetics of Collective Memories in Reform China, Washington, DC, Woodrow Wilson Center Press, 2007, pp. 1-20.

17. Ibid., p. 2.

18. Yuezhi Zhao, Communications in China: Political Economy, Power and Conflict, op. cit., p. 11. 